\title{
Th-rich loparite from the Khibina alkaline complex, Kola Peninsula: isomorphism and paragenesis
}

\author{
Roger H. Mitchell
}

AND

Anton R. Chakhmouradian

Department of Geology, Lakehead University, 955 Oliver Road, Thunder Bay, Ontario P7B 5E1, Canada

\section{ABSTRACT}

Th-rich (up to 18.4 wt. $\% \mathrm{ThO}_{2}$ ) loparite occurs as an accessory phase in foyaite pegmatites at Mt. Eveslogchorr, Khibina complex, Russia. It is associated with aegirine, astrophyllite, eudialyte, lorenzenite, lamprophyllite, magnesio-arfvedsonite and gerasimovskite. Loparite crystals are zoned from niobian loparite (core) to niobian thorian and thorian niobian loparite (rim). Th-enrichment is accompanied by a decrease in $\mathrm{Na}, L R E E, \mathrm{Sr}$ and increase in A-site vacancies. The most Th-rich composition approaches $\left(\mathrm{Na}_{0.39} L R E E_{0.19} \mathrm{Th}_{0.12} \mathrm{Ca}_{0.05} \mathrm{Sr}_{0.02}\right)_{\Sigma 0.77}\left(\mathrm{Ti}_{0.76} \mathrm{Nb}_{0.27}\right)_{\Sigma 1.03} \mathrm{O}_{3}$. The mineral is partly or completely metamict and after annealing gives an X-ray diffraction powder pattern similar to that of synthetic $\mathrm{NaLaTi}_{2} \mathrm{O}_{6}$ and naturally occurring loparite of different composition. For the Th-rich rim sample, the five strongest diffraction lines $(\AA)$ are: 2.72 (100) 110, 1.575 (60) 211, 1.925 (40), 1.368 (30) $220,1.222$ (20) $310 ; a=3.867(2) \AA$. The X-ray diffraction patterns do not exhibit peak splitting or other diffraction lines typical of low-symmetry and ordered perovskite-type structures. Composition determinations, infrared transmission spectroscopy and X-ray diffractometry show that thorian loparite is partly replaced by betafite with $L R E E$ and Th as dominant $A$-site cations ('ceriobetafite'). Some loparite samples also exhibit thin replacement mantles of belyankinite with high $L R E E_{2} \mathrm{O}_{3}$ and $\mathrm{ThO}_{2}$ contents. Both 'ceriobetafite' and belyankinite were formed due to metasomatic alteration of loparite.

KeYwords: loparite, betafite, belyankinite, nepheline-syenite pegmatite, Khibina alkaline complex, Kola Peninsula, Russia.

\section{Introduction}

PEROVSKITE-GROUP minerals from alkaline rocks exhibit wide ranges in composition and may serve as sensitive indicators of evolutionary trends (Kukharenko and Bagdasarov, 1961; Mitchell, 1996; Mitchell and Chakhmouradian, 1996; Tikhonenkova et al., 1982). Comprehensive studies of isomorphic substitutions in naturallyoccurring perovskites are also very important for understanding the crystal chemistry of synthetic perovskite-type compounds that show a broad spectrum of electric and magnetic properties.

Among the least studied of perovskite-group minerals are species containing large-size high- valency cations, in particular, Th, other tetravalent actinides and $\mathrm{Ce}^{4+}$. The initial study of naturally-occurring perovskites enriched in actinide elements was undertaken by Borodin (1954), who suggested that accommodation of highvalency elements with large ionic radii in perovskite-group minerals is accompanied by the creation of vacancies at $A$ sites in the lattice and partial substitution of oxygen atoms by hydroxyl anions. The generalized formula proposed by Borodin (1954) for hydrous perovskite-group minerals containing considerable amounts of rare-earth or actinide elements is $A_{1-x} \mathrm{BO}_{3-x}$ $(\mathrm{OH})_{x}(x=0-0.5)$. Borodin and Kazakova (1954) reported the occurrence of Th-rich 
(13.0 wt. $\% \mathrm{ThO}_{2}$ ) loparite (termed 'irinite') with minor amounts of $\mathrm{Fe}_{2} \mathrm{O}_{3}$ and $\mathrm{CaO}$ in a foyaite pegmatite at Mt. Eveslogchorr, in the Khibina alkaline complex, Kola Peninsula. The structural formula deduced from bulk wet-chemical analysis indicated that this mineral had significant cation deficiency at the $A$ sites which was associated with $\mathrm{O}^{2-} \rightleftharpoons(\mathrm{OH})^{-}$substitution (Borodin and Kazakova, 1954). Recent studies of loparite mineralization at the Khibina complex (Kozyreva et al., 1991; Tikhonenkova et al., 1982) also report the occurrence of Th-rich loparite in foyaite or related pegmatites. Parker and Sharp (1970) have described 'irinite' as an accessory constituent of vermiculite rock at the Gem Park Complex, Colorado. However, identification of this mineral as 'irinite' was based merely on its metamict state and resemblance of the X-ray diffraction pattern of the heated sample to that of Borodin and Kazakova's (1954) material (Parker and Sharp, 1970). Perovskite with $\mathrm{ThO}_{2}$ content of up to $1.7 \mathrm{wt} . \%$ occurs in the Polino carbonatite diatreme, Italy (Lupini et al., 1992), and up to 4.9 wt. \% in the carbonatite complexes of Kola Peninsula (Chakhmouradian and Mitchell, 1997). Finally, fenite-like rocks in the carbonatite complexes of the Paraná Basin, South America, host loparite of widely varying $\mathrm{SrO}, \mathrm{Na}_{2} \mathrm{O}, \mathrm{Nb}_{2} \mathrm{O}_{5}, L R E E_{2} \mathrm{O}_{3}$ and $\mathrm{ThO}_{2}$ (up to 6.2 wt. \%) contents (Mitchell, 1996).

Initial synthesis of Th-bearing perovskite-type oxides produced compounds of the type $A \mathrm{ThO}_{3}(A$ $=\mathrm{Ca}, \mathrm{Sr}, \mathrm{Ba}, \mathrm{Pb})$, in which $\mathrm{Th}^{4+}$ occupies octahedrally-coordinated B-sites (Náray-Szabó, 1947; Smith and Welch, 1960). Subsequently, Kovba and Trunov (1962) synthesized a series of niobates and tantalates accommodating $\mathrm{Th}, \mathrm{U}$ and $\mathrm{Ce}^{4+}$ at twelve-coordinated A-sites in the perovskite structure. These compounds were highly cation-deficient relative to ideal $A B X_{3}$ perovskite, having the general formula $A_{1 / 4} B_{3}(A$ $=\mathrm{Th}, \mathrm{U}, \mathrm{Ce} ; B=\mathrm{Nb}, \mathrm{Ta}$ ). Trunov and Kovba (1963) also prepared perovskite-type tungstates of Th, tolerating even higher cation deficiency at the A sites i.e. $\mathrm{Th}_{1 / 4} \mathrm{WO}_{3}$ to $\mathrm{Th}_{1 / 30} \mathrm{WO}_{3}$. Other synthetic perovskites with $A$-site $\mathrm{Th}$ include $\mathrm{CaThV}_{2} \mathrm{O}_{6}$ and $\operatorname{SrThV}_{2} \mathrm{O}_{6}$ (Vidyasagar and Gopalakrishnan, 1982), $\mathrm{Na}_{2 / 3} \mathrm{Th}_{1 / 3} \mathrm{TiO}_{3}$ (Zhu and Hor, 1995) and the solid solution series $\mathrm{NaNbO}_{3}-\mathrm{Th}_{0.25} \mathrm{NbO}_{3}$ (Labeau and Joubert, 1978). The above examples demonstrate that: (i) $\mathrm{Th}^{4+}$ in perovskite-type compounds may occupy either twelve-coordinated $A$ sites or smaller octahedral $B$ sites, depending on the type of associated cations; (ii) accommodation of Th in the perovskite structure may or may not be accompanied by the appearance of vacancies at the $A$ sites.

The current study was undertaken to determine how $\mathrm{Th}$ is accommodated in the structure of loparite, a Na-LREE-Ti member of the perovskite family containing significant amounts of $\mathrm{Nb}, \mathrm{Ca}$ and Sr. A second objective was to study the paragenesis of Th-rich loparite.

\section{Analytical methods}

All mineral compositions were determined by $\mathrm{X}$ ray energy-dispersion spectrometry using a Hitachi 570 scanning electron microscope equipped with a LINK ISIS analytical system incorporating a Super ATW Light Element Detector (133 eV FwHm $\mathrm{MnK}$ ) at Lakehead University, Ontario. EDS spectra of loparite, betafite and belyankinite were acquired for 300 seconds and those of silicates for 100 seconds (live time) with an accelerating voltage of $20 \mathrm{kV}$ and beam current of $0.86 \mathrm{nA}$. The following wellcharacterized natural and synthetic standards were employed for the determination of mineral compositions: Khibina loparite ( $\mathrm{Na}, L R E E, \mathrm{Nb})$, Magnet Cove perovskite ( $\mathrm{Ca}, \mathrm{Fe}, \mathrm{Ti})$, jadeite ( $\mathrm{Al}$, $\mathrm{Si})$, periclase $(\mathrm{Mg})$, orthoclase $(\mathrm{K})$, manganoan fayalite (Mn), synthetic $\mathrm{SrTiO}_{3}(\mathrm{Sr}), \mathrm{BaSiO}_{3}(\mathrm{Ba})$, metallic Th, Ta and Zr. The accuracy of the method was cross-checked by wave-lengthdispersion electron microprobe analysis using an automated CAMECA SX-50 microprobe located at the University of Manitoba following methods described by Mitchell and Vladykin (1993).

$\mathrm{X}$-ray diffraction (XRD) powder patterns $(\mathrm{Cu}$ radiation) were obtained with a Philips 3710 diffractometer at Lakehead University using a Philips Debye-Scherer type camera with a diameter of $114.6 \mathrm{~mm}$. The diffractometer was operated at $40 \mathrm{kV}$ and $25 \mathrm{~mA}$. Relative intensities of the diffraction lines were estimated visually from the films.

Infra-red transmission spectra were recorded with a FTIR spectrometer IFS-66 equipped with a microscope. Spectra were obtained on $0.2-0.3$ $\mathrm{mm}$ thick unfractured slabs of loparite from 256 scans using the $0.3-\mathrm{mm}$ aperture of the microscope. For each measurement, the reference spectrum was obtained from 256 scans at the same operating conditions in order to eliminate the effect of $\mathrm{H}_{2} \mathrm{O}$ vapour apparently present in the spectrometer. 


\section{Occurrence}

Until recently, loparite with the $\mathrm{ThO}_{2}$ content of more than $10 \mathrm{wt} . \%$ has been recognized only from the Khibina alkaline complex, in the Kola Peninsula, Russia. Its occurrence is restricted mainly to foyaite and related pegmatoid and metasomatic rocks comprising the central part of the Khibina pluton. The general geology, petrology and mineralogy of the complex have been described in detail by Galakhov (1975), Kostyleva-Labuntsova et al. (1978a,b), Zak et al. (1972) and summarized by Kogarko et al. (1995).

Th-rich loparite examined in the current study occurs in foyaite pegmatites exposed on the southern slope of Mt. Eveslogchorr, south Khibina. Most of the pegmatites are simple poorly-differentiated veins emplaced into fineto-medium grained nepheline syenite of gneissoid texture. The veins are composed mainly of alkali feldspar, nepheline, aegirine and astrophyllite. The latter two minerals occur in intimate intergrowths as fibrous or radial aggregates partly or entirely replacing the earlier formed paragenesis of alkali feldspar and nepheline. In Russian mineralogical literature, the late-stage zones of fibrous aegirine in nepheline-syenite pegmatites are commonly interpreted as being of deuteric ('autometasomatic') origin (KostylevaLabuntsova et al., 1978a). The aegirine-astrophyllite aggregate encloses numerous irregular-or lens-shaped polygranular segregations of analcite, phillipsite, natrolite and gibbsite plus Fe-hydroxides. These segregations commonly contain relics of nepheline and undoubtedly, represent alteration products of the latter. Accessory minerals developed in the aegirine-astrophylite aggregate are eudialyte, loparite, lamprophyllite, lorenzenite and rare magnesio-arfvedsonite. Representative compositions of the major and accessory silicates from the aegirine-astrophyllite rock are given in Table 1 .

In the aegirine-astrophyllite aggregate, loparite occurs as 'fluorite'-type interpenetration twins ranging from $3-7 \mathrm{~mm}$ across. The mineral is deep reddish-brown in thin sections and commonly has a yellow-coloured rim up to $0.3 \mathrm{~mm}$ in thickness. Some loparite crystals poikilitically enclose fine (less than $10 \mu \mathrm{m}$ ) needles of aegirine. In this study, we examined zoned crystals of loparite from two pegmatite veins: KHB-44 and KHB-70.
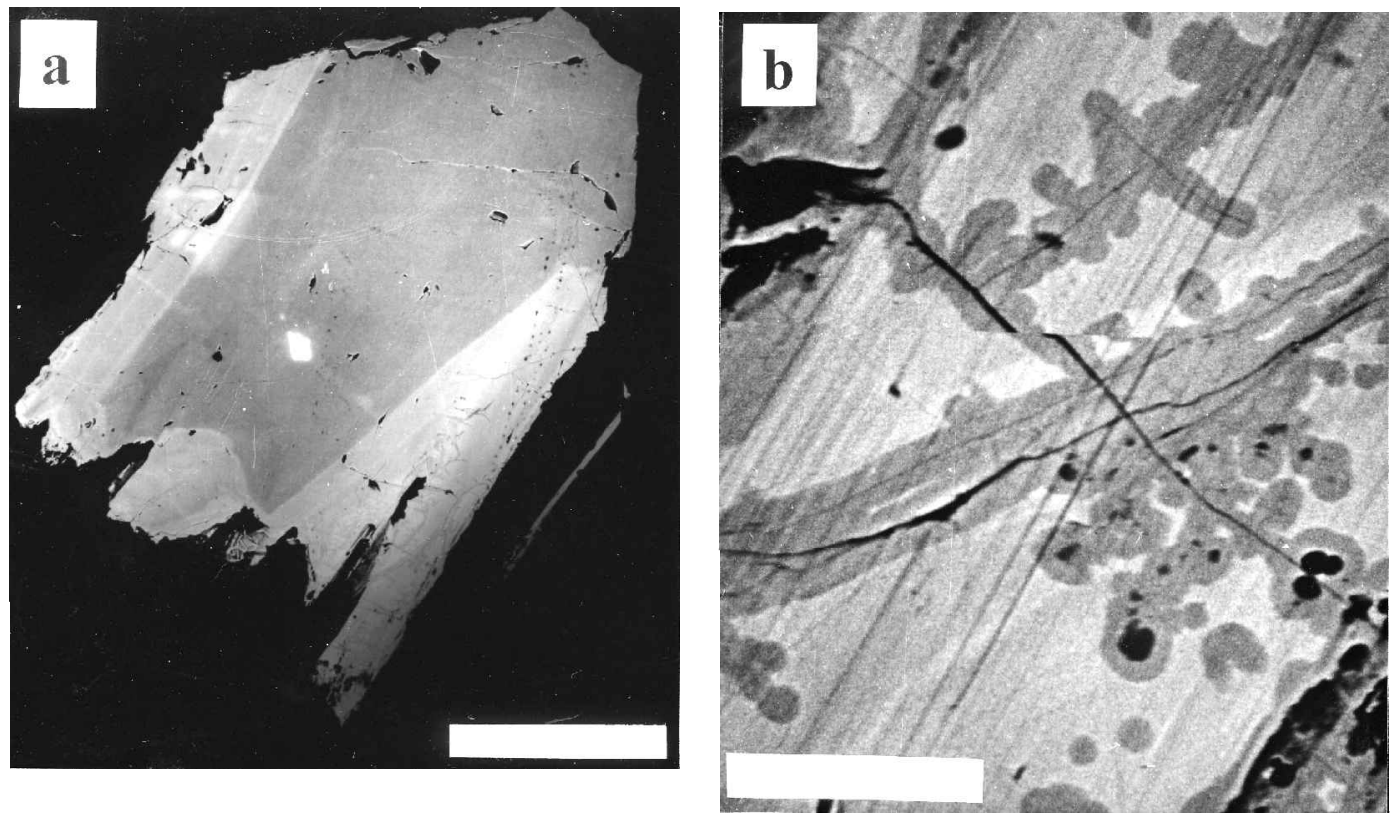

FIG. 1. Back-scattered electron images of a zoned Th-rich loparite crystal. (a) rim of thorian niobian and niobian thorian loparite (light grey) on niobian loparite (dark grey), scale bar is $400 \mu \mathrm{m}$; (b) 'ceriobetafite' (dark grey) developed along fractures and margins of thorian niobian loparite (light grey), scale bar is $30 \mu \mathrm{m}$. 


\section{Phase relationships}

Back-scattered electron (BSE) imagery combined with line scanning reveals that loparite crystals exhibit strong compositional zonation reflecting enrichment in $\mathrm{ThO}_{2}$ from the core towards the rim (Fig. 1a). The Th-rich rims of the crystals are heterogeneous and consist of two phases. Phase 1 having a lower average atomic number, is developed as dendrite-like narrow $(3-30 \mu \mathrm{m})$ zones decorating margins of the crystals and fractures within phase 2 (Fig. $1 b$ ). Composition determinations show that both phases have comparable $\mathrm{CaO}, \mathrm{SrO}, L R E E_{2} \mathrm{O}_{3}, \mathrm{TiO}_{2}$ and $\mathrm{Nb}_{2} \mathrm{O}_{5}(\mathrm{Ti}>\mathrm{Nb})$ contents. However, phase 1 gives low analysis totals (93.6-97.0 wt.\%) and contains considerably less $\mathrm{Na}_{2} \mathrm{O}(0.3-1.0$ wt. $\%)$ and generally more $\mathrm{ThO}_{2}(17.8-22.0$ wt. $\%)$ than phase 2. X-ray diffraction study (see below) demonstrates that phase 1 comprising the bulk of the sample extracted from the rim of the crystal is loparite. Three 'additional' weak diffraction lines observed on the XRD film could not be assigned to loparite or any structure derived from the perovskite parent, but corresponded well with the three strongest diffraction lines of betafite (ASTM 13-197: Hogarth, 1961).

Infrared transmission spectra recorded from the core and rim of a loparite crystal are compared in Fig. 2(a,b). Both spectra show a broad absorption band at $650-900 \mathrm{~cm}^{-1}$. This band corresponds to bond vibrations in the octahedral complexes $(\mathrm{Ti}, \mathrm{Nb}) \mathrm{O}_{6}$ and is typical of various perovskiteand pyrochlore-group minerals (KostylevaLabuntsova et al., 1978b; Pilipenko et al., 1971) and their synthetic analogues (Nyquist and Kagel,
1971; Sych et al., 1973). The relative position of this absorption band in the spectrum depends on the Ti vs. $\mathrm{Nb}$ ratio of the mineral. Splitting of the $(\mathrm{Ti}, \mathrm{Nb}) \mathrm{O}_{6}$ band commonly observed in the infrared spectra of low-symmetry perovskitetype compounds (Pilipenko et al., 1971; Sych et al., 1973) is not observed in our spectra (Fig. 2a,b). Similar coalescence of several absorption lines into one broad band has been observed in metamict pyrochlore (Krivokoneva and Sidorenko, 1971). In addition to the $(\mathrm{Ti}, \mathrm{Nb}) \mathrm{O}_{6}$ absorption band, the infrared spectrum of the rim (Fig. 2b) contains bands at 1650, 2330, 3300-3320 and $3530 \mathrm{~cm}^{-1}$, the latter two partially overlapping each other. The $\mathrm{OH}$ stretching bands at $3300-3320$ and $3530 \mathrm{~cm}^{-1}$ and $\mathrm{Nb}-\mathrm{OH}$ band at $1650 \mathrm{~cm}^{-1}$ are characteristic of pyrochlore-group minerals (Voloshin et al., 1989) and most probably result from microintergrowths of ceriobetafite in the studied samples. In the current study, we could not assign the absorption band at $2330 \mathrm{~cm}^{-1}$.

As evidenced by back-scattered electron imagery, loparite from the vein KHB-70 has undergone further alteration giving rise to the complex Ti hydroxide belyankinite. The mineral occurs as thin $(20-30 \mu \mathrm{m})$ replacement mantles on loparite. Its $\mathrm{Nb}$-dominant analogue gerasimovskite forms rare rectangular plates enclosed in fibrous aegirine. Both minerals have been insufficiently studied and were originally described in peralkaline pegmatites of the Lovozero alkaline complex, Kola Peninsula, where they occur predominantly as pseudomorphs after titanium-silicates (Gerasimovskii and Kazakova, 1950; Semenov, 1957).

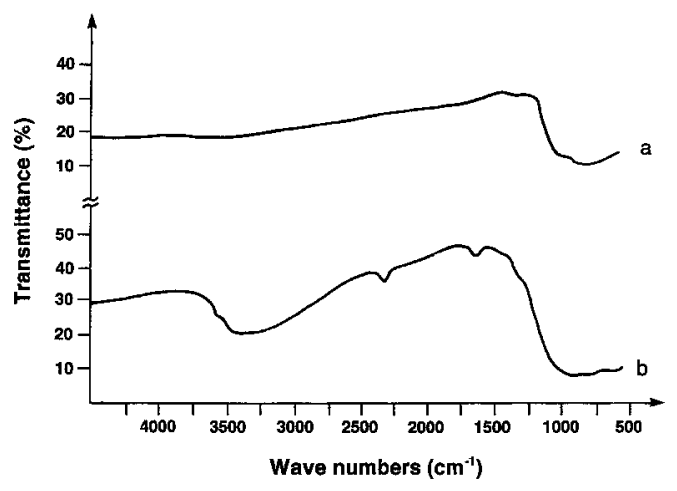

FIG. 2. Infra-red transmission spectra of Th-rich loparite. (a) core sample; $(b)$ rim sample.

\section{Composition}

\section{Loparite}

Representative compositions of zoned loparite crystals are given in Table 2 . From core to rim, loparite compositionally evolves by enrichment in $\mathrm{ThO}_{2}$ and depletion in $\mathrm{Na}_{2} \mathrm{O}, L R E E_{2} \mathrm{O}_{3}$ and $\mathrm{SrO}$ (Table 2). In order to reveal possible end-member compositions which may account for the accommodation of $\mathrm{Th}$ in the structure of loparite, relationships between the amounts of Th (apfu) and other major elements (Fig. 3) were analysed. With strongly decreasing $\mathrm{Na}, L R E E$ and to a lesser degree $\mathrm{Sr}$, and increasing Th (Fig. $3 a, b, d$ ), the occupancy of the $B$ sites remains relatively unchanged (Fig. 3e,f). As the most Th-rich compositions also exhibit the greatest cation 
TABLE 1. Representative compositions of major and accessory silicate minerals

\begin{tabular}{|c|c|c|c|c|c|c|c|c|c|c|c|c|}
\hline Wt. $\%$ & $1 *$ & $2 *$ & 3 & 4 & 5 & 6 & 7 & 8 & 9 & 10 & $11 *$ & $12 *$ \\
\hline $\mathrm{Na}_{2} \mathrm{O}$ & 12.81 & 12.20 & 2.27 & 2.16 & 11.24 & 10.94 & 10.66 & 11.04 & 17.07 & 16.96 & 8.89 & 8.71 \\
\hline $\mathrm{K}_{2} \mathrm{O}$ & 0.04 & 0.08 & 6.02 & 6.06 & 0.41 & 0.35 & 0.64 & 0.61 & n.d & n.d & 2.04 & 2.18 \\
\hline $\mathrm{CaO}$ & 2.25 & 2.67 & 1.41 & 1.55 & 9.29 & 8.79 & 0.45 & 0.40 & 0.05 & 0.08 & 0.56 & 0.67 \\
\hline $\mathrm{SrO}$ & n.a & n.a & n.d & n.d & 1.49 & 1.18 & 13.06 & 11.62 & n.d & n.d & n.a & n.a \\
\hline $\mathrm{BaO}$ & n.a & n.a & n.d & n.d & n.d & n.d & 0.85 & 3.22 & n.d & n.d & n.a & n.a \\
\hline $\mathrm{MgO}$ & 1.02 & 1.03 & 1.89 & 1.91 & 0.09 & 0.37 & 0.43 & 0.45 & 0.35 & 0.23 & 8.20 & 8.08 \\
\hline $\mathrm{MnO}$ & 0.37 & 0.39 & 12.92 & 13.29 & 3.83 & 4.52 & 5.58 & 5.26 & n.d & 0.12 & 3.73 & 3.83 \\
\hline $\mathrm{FeO}$ & 0.60 & 1.36 & 19.04 & 18.50 & 3.92 & 3.24 & n.a & n.a & n.a & n.a & 13.93 & 13.51 \\
\hline $\mathrm{Fe}_{2} \mathrm{O}_{3}$ & 26.70 & 25.35 & n.a & n.a & n.a & n.a & 2.93 & 2.50 & 0.80 & 0.69 & 5.92 & 6.62 \\
\hline $\mathrm{La}_{2} \mathrm{O}_{3}$ & n.a & n.a & n.d & n.d & 0.67 & 1.06 & 0.60 & 0.42 & n.a & n.a & n.a & n.a \\
\hline $\mathrm{Ce}_{2} \mathrm{O}_{3}$ & n.a & n.a & n.d & n.d & 1.40 & 1.31 & 0.52 & 0.26 & n.a & n.a & n.a & n.a \\
\hline $\mathrm{Al}_{2} \mathrm{O}_{3}$ & 1.65 & 1.17 & 0.86 & 1.04 & n.d & n.d & 0.29 & 0.02 & n.d & n.d & 1.01 & 1.30 \\
\hline $\mathrm{SiO}_{2}$ & 53.26 & 51.96 & 35.55 & 35.50 & 49.95 & 48.52 & 31.00 & 30.35 & 33.31 & 33.82 & 53.20 & 52.36 \\
\hline $\mathrm{TiO}_{2}$ & 1.81 & 1.97 & 11.60 & 11.57 & 0.40 & 0.23 & 29.59 & 29.91 & 44.79 & 45.16 & 0.98 & 1.25 \\
\hline $\mathrm{ZrO}_{2}$ & n.a & n.a & 0.65 & 0.49 & 13.26 & 12.20 & n.d & n.d & n.d & n.d & n.a & n.a \\
\hline $\mathrm{Nb}_{2} \mathrm{O}_{5}$ & n.a & n.a & 0.65 & 0.77 & 2.90 & 3.31 & 0.09 & 0.41 & 2.12 & 1.88 & n.a & n.a \\
\hline Total & 100.52 & 98.18 & 92.86 & 92.84 & 98.85 & 96.02 & 96.69 & 96.47 & 98.49 & 98.94 & 98.46 & 98.51 \\
\hline \multicolumn{13}{|c|}{ Structural formulae: } \\
\hline & \multicolumn{2}{|c|}{$\mathrm{O}=6$} & \multicolumn{2}{|c|}{$\mathrm{Si}=8$} & \multicolumn{2}{|c|}{$\mathrm{Si}=24$} & \multicolumn{2}{|c|}{$\mathrm{Si}=4$} & \multicolumn{2}{|c|}{$\mathrm{O}=9$} & \multicolumn{2}{|c|}{$\mathrm{O}=23$} \\
\hline $\mathrm{Na}$ & 0.934 & 0.913 & 0.990 & 0.944 & 10.471 & 10.492 & 2.667 & 2.821 & 1.929 & 1.904 & 2.576 & 2.530 \\
\hline K & 0.002 & 0.004 & 1.728 & 1.742 & 0.251 & 0.221 & 0.105 & 0.103 & - & - & 0.389 & 0.417 \\
\hline $\mathrm{Ca}$ & 0.091 & 0.111 & 0.340 & 0.374 & 4.782 & 4.658 & 0.062 & 0.056 & 0.003 & 0.005 & 0.090 & 0.107 \\
\hline $\mathrm{Sr}$ & - & - & - & - & 0.415 & 0.338 & 0.977 & 0.888 & - & - & - & - \\
\hline $\mathrm{Ba}$ & - & - & - & - & - & - & 0.043 & 0.166 & - & - & - & - \\
\hline $\mathrm{Mg}$ & 0.057 & 0.059 & 0.634 & 0.642 & 0.064 & 0.273 & 0.083 & 0.088 & 0.030 & 0.020 & 1.827 & 1.804 \\
\hline $\mathrm{Mn}$ & 0.012 & 0.013 & 2.463 & 2.537 & 1.559 & 1.894 & 0.610 & 0.587 & - & 0.006 & 0.472 & 0.486 \\
\hline $\mathrm{Fe}^{2+}$ & 0.020 & 0.047 & 3.583 & 3.486 & 1.575 & 1.340 & - & - & - & - & 1.742 & 1.693 \\
\hline $\mathrm{Fe}^{3+}$ & 0.756 & 0.735 & - & - & - & - & 0.284 & 0.248 & 0.035 & 0.0300 & 0.666 & 0.747 \\
\hline $\mathrm{La}$ & - & - & - & - & 0.119 & 0.193 & 0.029 & 0.020 & - & - & - & - \\
\hline $\mathrm{Ce}$ & - & - & - & - & 0.246 & 0.237 & 0.025 & 0.013 & - & - & - & - \\
\hline $\mathrm{Al}$ & 0.073 & 0.054 & 0.228 & 0.276 & - & - & 0.044 & 0.003 & - & - & 0.178 & 0.229 \\
\hline $\mathrm{Si}$ & 2.003 & 2.007 & 8.000 & 8.000 & 24.000 & 24.000 & 4.000 & 4.000 & 1.942 & 1.958 & 7.951 & 7.845 \\
\hline $\mathrm{Ti}$ & 0.052 & 0.057 & 1.963 & 1.961 & 0.145 & 0.086 & 2.871 & 2.964 & 1.963 & 1.966 & 0.110 & 0.141 \\
\hline $\mathrm{Zr}$ & - & - & 0.071 & 0.054 & 3.107 & 2.943 & - & - & - & - & - & - \\
\hline $\mathrm{Nb}$ & - & - & 0.066 & 0.078 & 0.630 & 0.740 & 0.005 & 0.024 & 0.056 & 0.049 & - & - \\
\hline
\end{tabular}

Compositions: 1 and 2 aegirine; 3 and 4 astrophyllite; 5 and 6 eudialyte; 7 and 8 lamprophyllite; 9 and 10 lorenzenite; 11 and 12 magnesio-arfvedsonite.

All data this work.

* $\mathrm{Fe}^{2+} / \mathrm{Fe}^{3+}$ ratio calculated using Droop's (1987) method;

deficiency (Fig. $3 g$ ), it is deduced that $\mathrm{Th}^{4+}$ cations are accommodated at the $A$ site of loparite, and that the corresponding substitution scheme involves the appearance of vacancies at these sites. Calculations show that the observed relationship between $\mathrm{Th}$ content and number of vacancies at the A-site most closely corresponds to the solid solution series between loparite and two hypothetical endmembers: $\mathrm{ThNb}_{4} \mathrm{O}_{12}$ and $\mathrm{ThTi}_{2} \mathrm{O}_{6}$ (Fig. 3). The solid solution series between loparite
$\mathrm{NaLREETi} \mathrm{O}_{6}$ and $\mathrm{Na}_{2 / 3} \mathrm{Th}_{1 / 3} \mathrm{TiO}_{3}$, believed to be present, is not present as the $A$ - and $B$-sites occupancy remains constant. The isomorphic substitutions are as follows:

$$
\begin{gathered}
2 \mathrm{Na}^{+}+2 L^{2} E E^{3+}+4 \mathrm{Ti}^{4+} \rightleftharpoons \\
\mathrm{Na}^{+}+L R E E^{3+} \rightleftharpoons \mathrm{Th}^{4+}+3 \square+4 \mathrm{~Tb}^{4+}+\square
\end{gathered}
$$

$\mathrm{ThNb}_{4} \mathrm{O}_{12}\left(=\mathrm{Th}_{0.25} \mathrm{NbO}_{3}\right)$ has been synthesized and shown to have a perovskite-type 
TABLE 2. Representative compositions of loparite

\begin{tabular}{|c|c|c|c|c|c|c|c|c|c|}
\hline Wt. $\%$ & 1 & 2 & 3 & 4 & 5 & 6 & 7 & 8 & 9 \\
\hline $\mathrm{Na}_{2} \mathrm{O}$ & 10.43 & 8.68 & 8.50 & 7.42 & 6.69 & 9.71 & 9.18 & 7.66 & 6.62 \\
\hline $\mathrm{CaO}$ & 1.53 & 1.59 & 1.71 & 1.50 & 1.63 & 1.82 & 2.08 & 1.62 & 1.86 \\
\hline $\mathrm{SrO}$ & 1.40 & 1.33 & 1.29 & 1.33 & 1.09 & 1.65 & 1.77 & 1.31 & 1.20 \\
\hline $\mathrm{La}_{2} \mathrm{O}_{3}$ & 9.72 & 8.88 & 6.47 & 6.46 & 5.41 & 11.42 & 9.37 & 8.24 & 5.79 \\
\hline $\mathrm{Ce}_{2} \mathrm{O}_{3}$ & 14.77 & 14.21 & 11.19 & 10.27 & 8.91 & 16.91 & 14.64 & 13.37 & 9.87 \\
\hline $\mathrm{Pr}_{2} \mathrm{O}_{3}$ & 1.86 & 1.72 & 1.56 & n.d & 1.14 & 1.03 & 2.20 & 2.54 & 1.38 \\
\hline $\mathrm{Nd}_{2} \mathrm{O}_{3}$ & 2.04 & 2.02 & 1.56 & 1.96 & 1.86 & 1.61 & 2.47 & 1.98 & 1.95 \\
\hline $\mathrm{ThO}_{2}$ & 3.46 & 7.38 & 10.29 & 15.40 & 18.45 & 2.34 & 3.66 & 8.69 & 17.28 \\
\hline $\mathrm{TiO}_{2}$ & 32.39 & 33.08 & 30.46 & 33.65 & 33.72 & 34.37 & 32.41 & 33.55 & 34.80 \\
\hline $\mathrm{FeO}$ & 0.12 & 0.07 & 0.07 & n.d. & 0.11 & 0.07 & n.d. & 0.11 & 0.48 \\
\hline $\mathrm{Nb}_{2} \mathrm{O}_{5}$ & 21.38 & 21.98 & 27.16 & 22.10 & 20.18 & 18.72 & 22.13 & 20.34 & 19.62 \\
\hline $\mathrm{Ta}_{2} \mathrm{O}_{5}$ & 0.37 & 0.22 & 0.32 & 0.43 & 0.30 & 0.33 & 0.49 & 0.59 & 0.58 \\
\hline Total & 99.47 & 101.16 & 100.58 & 100.52 & 99.49 & 99.98 & 100.40 & 100.00 & 101.43 \\
\hline \multicolumn{10}{|c|}{ Structural formulae $(\mathrm{O}=3)$} \\
\hline $\mathrm{Na}$ & 0.589 & 0.486 & 0.477 & 0.420 & 0.387 & 0.545 & 0.515 & 0.436 & 0.375 \\
\hline $\mathrm{Ca}$ & 0.048 & 0.049 & 0.053 & 0.047 & 0.052 & 0.056 & 0.064 & 0.051 & 0.058 \\
\hline $\mathrm{Sr}$ & 0.024 & 0.022 & 0.022 & 0.022 & 0.019 & 0.028 & 0.030 & 0.022 & 0.020 \\
\hline $\mathrm{La}$ & 0.104 & 0.095 & 0.069 & 0.070 & 0.060 & 0.122 & 0.100 & 0.089 & 0.062 \\
\hline $\mathrm{Ce}$ & 0.158 & 0.150 & 0.118 & 0.110 & 0.097 & 0.179 & 0.155 & 0.144 & 0.106 \\
\hline $\operatorname{Pr}$ & 0.020 & 0.018 & 0.016 & 0.000 & 0.012 & 0.011 & 0.023 & 0.027 & 0.015 \\
\hline $\mathrm{Nd}$ & 0.021 & 0.021 & 0.016 & 0.020 & 0.020 & 0.017 & 0.026 & 0.021 & 0.020 \\
\hline Th & 0.023 & 0.048 & 0.067 & 0.102 & 0.125 & 0.015 & 0.024 & 0.058 & 0.115 \\
\hline $\mathrm{Ti}$ & 0.710 & 0.719 & 0.663 & 0.739 & 0.756 & 0.749 & 0.705 & 0.741 & 0.764 \\
\hline $\mathrm{Fe}$ & 0.003 & 0.002 & 0.002 & 0.000 & 0.003 & 0.002 & 0.000 & 0.002 & 0.012 \\
\hline $\mathrm{Nb}$ & 0.282 & 0.287 & 0.355 & 0.292 & 0.272 & 0.245 & 0.290 & 0.270 & 0.259 \\
\hline Ta & 0.003 & 0.002 & 0.002 & 0.003 & 0.002 & 0.003 & 0.004 & 0.005 & 0.005 \\
\hline \multicolumn{10}{|c|}{ Mol. $\%$ end-members } \\
\hline $\mathrm{NaCeTi}_{2} \mathrm{O}$ & 60.10 & 57.99 & 45.93 & 43.06 & 40.47 & 65.80 & 61.03 & 58.33 & 43.68 \\
\hline $\mathrm{NaNbO}_{3}$ & 28.20 & 20.62 & 27.06 & 23.68 & 21.20 & 21.60 & 21.18 & 16.09 & 18.50 \\
\hline $\mathrm{ThNb}_{4} \mathrm{O}_{12}$ & 0.00 & 8.68 & 10.17 & 7.75 & 7.92 & 2.90 & 7.93 & 11.94 & 9.36 \\
\hline $\mathrm{ThTi}_{2} \mathrm{O}_{6}$ & 4.56 & 5.46 & 8.97 & 18.08 & 22.81 & 1.55 & 0.43 & 6.07 & 20.06 \\
\hline $\mathrm{CaTiO}_{3}$ & 4.76 & 5.00 & 5.56 & 5.06 & 5.57 & 5.60 & 6.42 & 5.29 & 6.25 \\
\hline $\mathrm{SrTiO}_{3}$ & 2.38 & 2.25 & 2.31 & 2.37 & 2.03 & 2.55 & 3.01 & 2.28 & 2.15 \\
\hline
\end{tabular}

Compositions: $1-2$ core and 3-5 rim of a zoned loparite crystal KHB $-44,6-7$ core and $8-9$ rim of a zoned loparite crystal KHB-70.

All data this work.

Total $\mathrm{Fe}$ expressed as $\mathrm{FeO}$; n.d. $=$ not detected.

structure (Keller, 1965; Kovba and Trunov, 1963). Thorium dititanate $\left(\mathrm{ThTi}_{2} \mathrm{O}_{6}\right)$ occurs in two polymorphs of monoclinic symmetry. Structures of both polymorphs differ from that of perovskite in being built of sheets of edgesharing $\mathrm{TiO}_{6}$ octahedra bound by $\mathrm{Th}$ atoms in either six-fold or eight-fold coordination (Balić Žunić et al., 1984; Ruh and Wadsley, 1966). Given the considerable structural difference, loparite and thorium dititanate apparently should not form a continuous solid solution series; however, limits of the solubility between these two end-members are unknown. Our data suggest at least $23 \mathrm{~mol} . \% \mathrm{ThTi}_{2} \mathrm{O}_{6}$ is possible.

The compositions of Th-rich loparite were recalculated into major perovskite-group endmembers (Mitchell, 1996) plus the two thorium compounds $\mathrm{ThNb}_{4} \mathrm{O}_{12}$ and $\mathrm{ThTi}_{2} \mathrm{O}_{6}$ (Table 2, Fig. 4). The loparite composition evolves by becoming enriched in the thorium end-members 

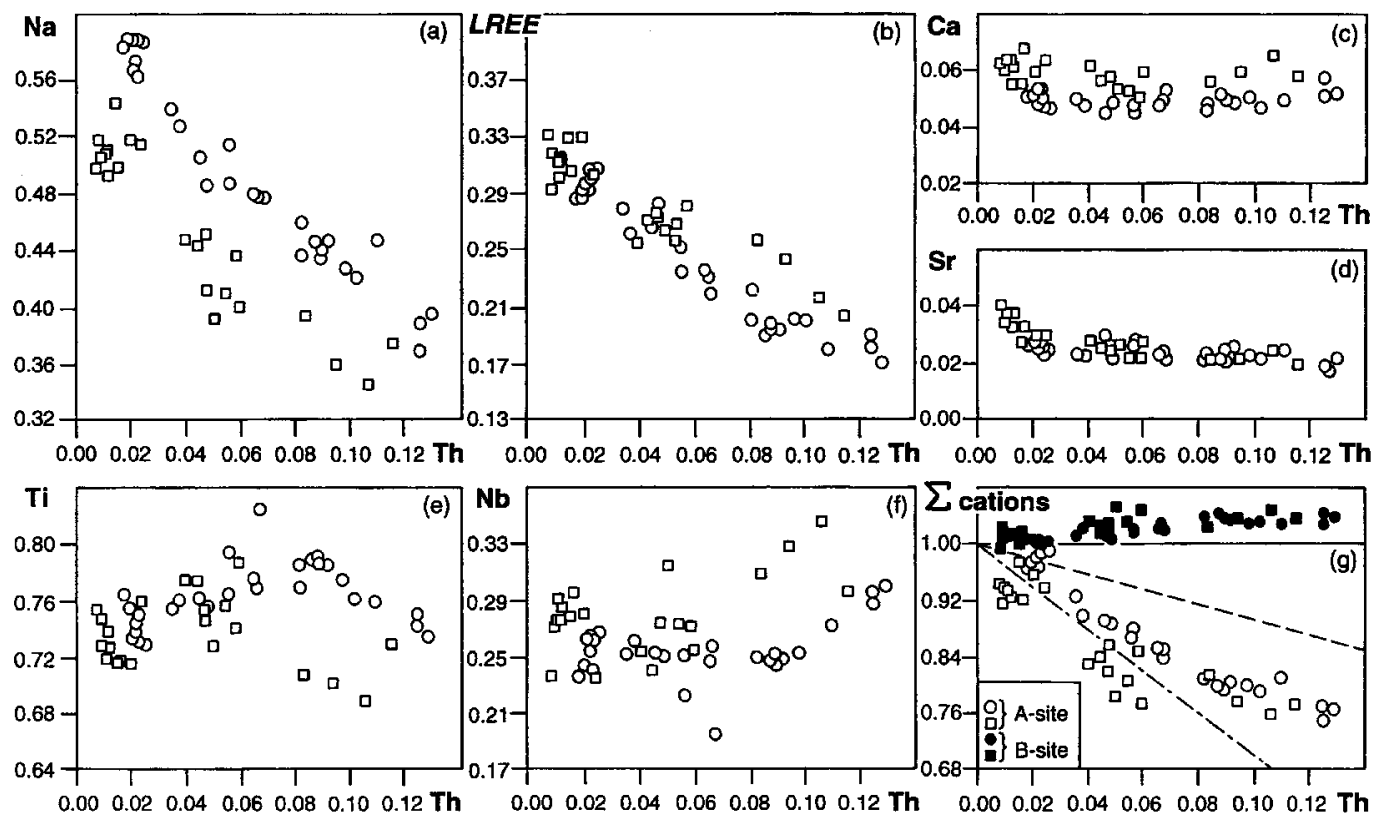

FIG. 3. Variations (apfu) of: (a) Na, (b) LREE, $(c) \mathrm{Ca},(d) \mathrm{Sr},(e) \mathrm{Ti},(f) \mathrm{Nb}$ and $(g)$ cation totals at the $A$ and $B$ sites, with respect to Th for Th-rich loparite. Circles correspond to loparite KHB-44, squares to KHB-70. Variation of $A$ cation totals in the solid solution series $\mathrm{NaLREETi}{ }_{2} \mathrm{O}_{6}-\mathrm{Na}_{2} \mathrm{ThTi}_{3} \mathrm{O}_{9}$ is shown by solid line, in the series $\mathrm{NaLREETi}_{2} \mathrm{O}_{6}-\mathrm{ThTi}_{2} \mathrm{O}_{6}$ by dashed line, and in the series $\mathrm{NaLREETi}_{2} \mathrm{O}_{6}-\mathrm{ThNb}_{4} \mathrm{O}_{12}$ by dash-dotted line $(g)$.

at essentially constant lueshite content. Using nomenclature principles suggested for the perovskite-group minerals by Mitchell (1996), the examined samples compositionally evolve from niobian loparite toward niobian thorian and thorian niobian loparite.

\section{Betafite}

Representative analyses of betafite developed in thorian loparite, are given in Table 3. LREE dominated by $\mathrm{Ce}$, and $\mathrm{Th}$ are the major $A$-cations. According to the classification scheme proposed by Hogarth (1989) for the pyrochlore-group minerals, this mineral should be regarded as ceriobetafite or thorium ceriobetafite (LREE > $\mathrm{Th}>20 \%$ cation sum at the $A$ sites). In this study, we prefer to refer to the mineral using quotation marks, as 'ceriobetafite' is not approved as a distinct mineral species by the Comission on New Minerals and Mineral Names of the IMA.

At the Khibina complex, pyrochlore-group minerals were previously described as accessory constituents of aegirine-feldspar veins (Kozyreva,
1990) and peralkaline pegmatites (Kapustin, 1989; Shilin et al., 1966). These minerals correspond to pyrochlore sensu stricto that may be somewhat enriched in SrO (Shilin et al., 1966) or LREE (Kapustin, 1989). Ti-dominant species, i.e. members of the betafite subgroup have not been previously recognized in the Khibina alkaline complex.

\section{Belyankinite}

Compositional data on belyankinite and related $\mathrm{Ti}-\mathrm{Nb}$ hydroxides available from literature are limited to a few bulk wet-chemical analyses (Gerasimovskii and Kazakova, 1950; Semenov, 1957; Vlasov et al., 1966). Semenov (1957) has suggested that Ti-dominant belyankinite forms solid solution series with its Mn-analogue manganbelyankinite and $\mathrm{Nb}$-dominant gerasimovskite. The mineral examined in the present study is a member of the belyankinite-gerasimovskite series with negligible content of manganbelyankinite (Table 4). A generalized structural formula of belyankinite calculated on the basis of 12 atoms of oxygen, is 

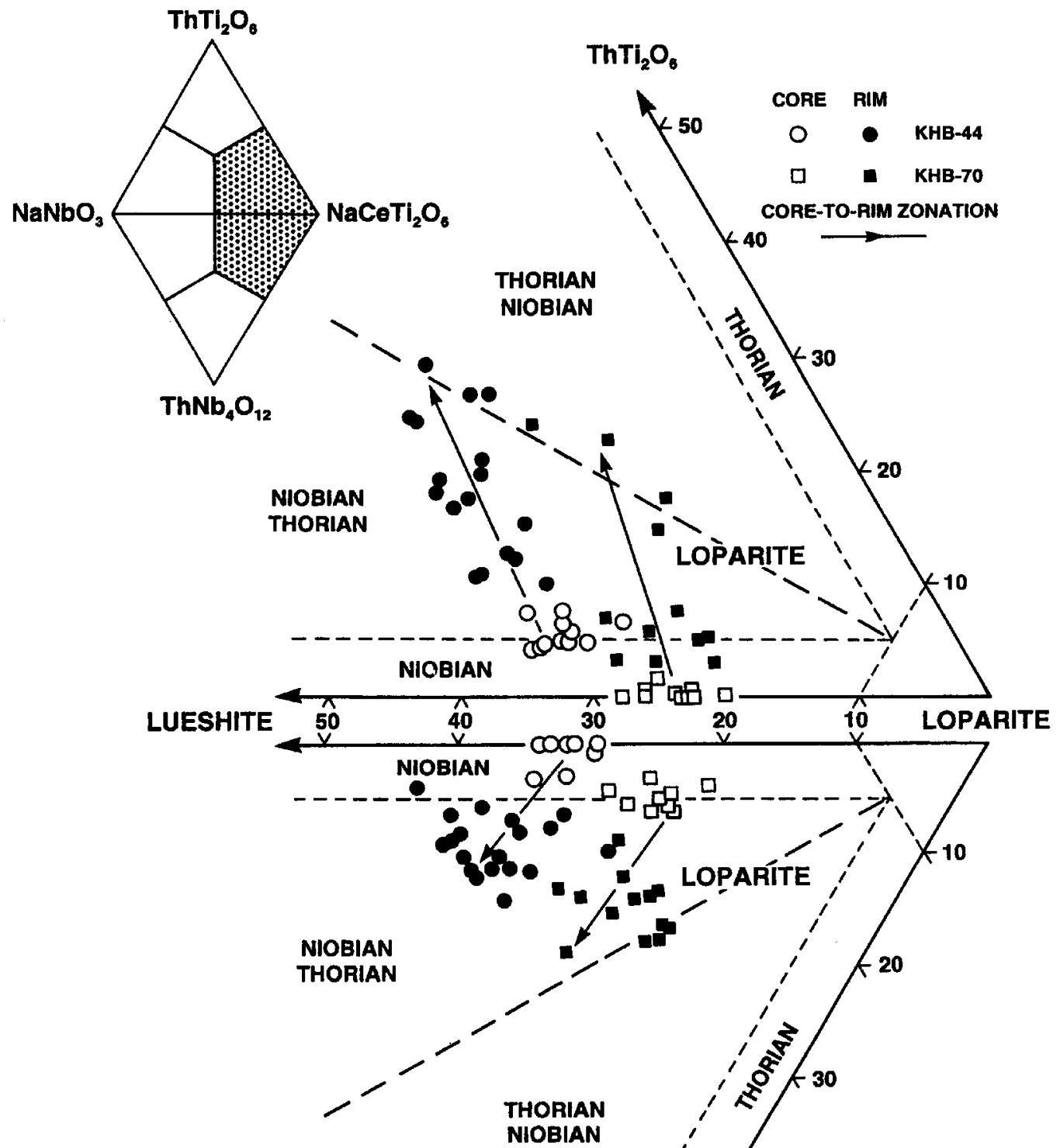
TABLE 3. Representative compositions of 'ceriobetafite'

\begin{tabular}{|c|c|c|c|c|c|c|c|}
\hline & 1 & 2 & 3 & & 1 & 2 & 3 \\
\hline Wt. $\%$ & & & & & \multicolumn{3}{|c|}{$\begin{array}{l}\text { Structural formulae } \\
(\Sigma \mathrm{B} \text {-cations }=2)\end{array}$} \\
\hline $\mathrm{Na}_{2} \mathrm{O}$ & 1.01 & 0.54 & 0.34 & $\mathrm{Na}$ & 0.111 & 0.060 & 0.036 \\
\hline $\mathrm{CaO}$ & 1.79 & 1.67 & 1.76 & $\mathrm{Ca}$ & 0.108 & 0.102 & 0.103 \\
\hline $\mathrm{SrO}$ & 1.17 & 1.15 & 1.30 & $\mathrm{Sr}$ & 0.038 & 0.038 & 0.041 \\
\hline $\mathrm{La}_{2} \mathrm{O}_{3}$ & 5.79 & 4.81 & 5.10 & $\mathrm{La}$ & 0.121 & 0.101 & 0.103 \\
\hline $\mathrm{Ce}_{2} \mathrm{O}_{3}$ & 9.01 & 8.65 & 8.46 & $\mathrm{Ce}$ & 0.186 & 0.180 & 0.169 \\
\hline $\mathrm{Nd}_{2} \mathrm{O}_{3}$ & 1.52 & 2.62 & 1.14 & $\mathrm{Nd}$ & 0.034 & 0.053 & 0.022 \\
\hline $\mathrm{ThO}_{2}$ & 19.65 & 20.88 & 20.41 & $\mathrm{Th}$ & 0.244 & 0.270 & 0.253 \\
\hline $\mathrm{TiO}_{2}$ & 33.82 & 35.06 & 37.50 & $\mathrm{Ti}$ & 1.438 & 1.499 & 1.539 \\
\hline $\mathrm{Fe}_{2} \mathrm{O}_{3}$ & n.d. & 0.03 & 0.47 & $\mathrm{Fe}$ & 0.000 & 0.001 & 0.017 \\
\hline $\mathrm{Nb}_{2} \mathrm{O}_{5}$ & 21.77 & 19.26 & 17.76 & $\mathrm{Nb}$ & 0.556 & 0.495 & 0.438 \\
\hline $\mathrm{Ta}_{2} \mathrm{O}_{5}$ & 0.37 & 0.34 & 0.39 & $\mathrm{Ta}$ & 0.006 & 0.005 & 0.006 \\
\hline Total & 95.40 & 95.01 & 94.63 & & & & \\
\hline
\end{tabular}

Compositions: 1 and 2 KHB-44, 3 KHB-70.

All data this work.

Total $\mathrm{Fe}$ expressed as $\mathrm{Fe}_{2} \mathrm{O}_{3}$; n.d. $=$ not detected.

$(\mathrm{Ca}, \mathrm{Th}, L R E E)_{1.3}(\mathrm{Ti}, \mathrm{Nb}, \mathrm{Si}, \mathrm{Fe})_{5} \mathrm{O}_{12} \cdot \mathrm{n} \mathrm{H}_{2} \mathrm{O}$ (average of 18 determinations) and approaches that deduced by Fleischer from Semenov's analytical data (see reference to Semenov, 1957): $\mathrm{Ca}_{0.9}(\mathrm{Ti}, \mathrm{Zr}, \mathrm{Nb}, \mathrm{Si})_{5.5} \mathrm{O}_{12} \cdot 10 \mathrm{H}_{2} \mathrm{O}$.
However, the mineral from Khibina differs from Lovozero belyankinite in having much higher $\mathrm{ThO}_{2}$ (up to 24.17 wt. \%) and $L R E E_{2} \mathrm{O}_{3}$ (up to 11.6 wt. $\%$ ) contents, both of which are undoubtedly 'inherited' from the loparite parent.

TABLE 4. Representative compositions of belyankinite

\begin{tabular}{|c|c|c|c|c|c|}
\hline & 1 & 2 & & 1 & 2 \\
\hline Wt. $\%$ & & & & \multicolumn{2}{|c|}{$\begin{array}{l}\text { Structural formulae } \\
\qquad(\mathrm{O}=24)\end{array}$} \\
\hline $\mathrm{Na}_{2} \mathrm{O}$ & 0.03 & 0.28 & $\mathrm{Na}$ & 0.014 & 0.122 \\
\hline $\mathrm{CaO}$ & 4.12 & 1.62 & $\mathrm{Ca}$ & 1.027 & 0.402 \\
\hline $\mathrm{MgO}$ & 0.16 & 0.17 & $\mathrm{Mg}$ & 0.055 & 0.060 \\
\hline $\mathrm{MnO}$ & 0.11 & 0.28 & $\mathrm{Mn}$ & 0.022 & 0.053 \\
\hline $\mathrm{La}_{2} \mathrm{O}_{3}$ & 2.08 & 2.00 & $\mathrm{La}$ & 0.179 & 0.169 \\
\hline $\mathrm{Ce}_{2} \mathrm{O}_{3}$ & 8.62 & 2.21 & $\mathrm{Ce}$ & 0.733 & 0.186 \\
\hline $\mathrm{Nd}_{2} \mathrm{O}_{3}$ & 0.81 & 0.76 & $\mathrm{Nd}$ & 0.067 & 0.062 \\
\hline $\mathrm{ThO}_{2}$ & 12.42 & 24.17 & Th & 0.657 & 1.264 \\
\hline $\mathrm{SiO}_{2}$ & 13.03 & 12.21 & $\mathrm{Si}$ & 3.033 & 2.805 \\
\hline $\mathrm{TiO}_{2}$ & 22.81 & 24.73 & $\mathrm{Ti}$ & 3.991 & 4.273 \\
\hline $\mathrm{Al}_{2} \mathrm{O}_{3}$ & 1.21 & 1.66 & $\mathrm{Al}$ & 0.331 & 0.450 \\
\hline $\mathrm{Fe}_{2} \mathrm{O}_{3}$ & 6.16 & 5.07 & $\mathrm{Fe}$ & 1.078 & 0.877 \\
\hline $\mathrm{Nb}_{2} \mathrm{O}_{5}$ & 15.02 & 15.87 & $\mathrm{Nb}$ & 1.578 & 1.649 \\
\hline Total & 86.58 & 91.03 & & & \\
\hline
\end{tabular}

Compositions: 1 and 2 replacement mantles on thorian loparite KHB-70.

Total $\mathrm{Fe}$ expressed as $\mathrm{Fe}_{2} \mathrm{O}_{3} ; \mathrm{ZrO}_{2}$ was sought, but not found. 


\section{X-ray powder diffractometry}

An XRD powder pattern of a sample of the core of a thorian loparite showed only a few faint diffraction lines with relatively high $d$-spacings, whereas a rim sample appeared to be completely metamict. After heating to $700^{\circ} \mathrm{C}$ for 1 hour, the core and rim samples gave XRD powder patterns (Table 5) similar to those of La-dominant synthetic loparite $\mathrm{NaLaTi}_{2} \mathrm{O}_{6}$ and 'irinite' as described by Borodin and Kazakova (1954). The former has been proposed to have the undistorted cubic lattice (ASTM 39-65: Belous et al., 1985). However, Rietveld refinement of an XRD powder pattern of $\mathrm{NaLaTi}_{2} \mathrm{O}_{6}$ suggests that this compound is orthorhombic (space group Pnma) rather than cubic (Mitchell and Chakhmouradian, in preparation) The pattern of the rim sample of thorian loparite also includes three diffraction lines with $d$-spacings of $2.95,1.795$ and $1.535 \AA$, that cannot be produced by the perovskite-type structure. These are characteristic of pyrochloretype phases and correspond to the most intense lines 222, 440 and 622, respectively (ASTM 13197; ASTM 17-746).
Data available from the literature show that XRD powder patterns similar to those obtained in this study are produced by naturally occurring loparite of various $\mathrm{Nb}_{2} \mathrm{O}_{5}, \mathrm{CaO}, \mathrm{Na}_{2} \mathrm{O}, \mathrm{TiO}_{2}$ and $\mathrm{SrO}$ contents (Haggerty and Mariano, 1983; Kostyleva-Labuntsova et al., 1978b; Mitchell et al., 1996). Given a significant difference in ionic radius between $\mathrm{Th}^{4+}, \mathrm{Na}^{+}$and $\mathrm{Ce}^{3+}(1.21,1.39$ and $1.34 \AA$, respectively: Shannon, 1976), it is expected that Th-rich loparite should have a strongly distorted perovskite-type structure. However, the obtained patterns (Table 5) do not exhibit 'extra' diffraction lines reflecting cation ordering or geometric distortion of the ideal cubic perovskite-type lattice. Such diffraction lines, e.g. $7.69-7.90,3.44-3.50,2.57-2.60,1.87-1.89 \AA$, are present in patterns of most synthetic perovskite-type titanates and niobates with $\mathrm{Th}^{4+}$ localized at the $A$ sites (Keller, 1965; Kovba and Trunov, 1963; Labeau and Joubert, 1978; Zhu and Hor, 1995). The only known exceptions so far are compounds from the $\mathrm{Na}_{0.6-0.8} \mathrm{Th}_{0.1-0.2} \mathrm{NbO}_{3}$ range of the $\mathrm{NaNbO}_{3}-\mathrm{Th}_{0.25} \mathrm{NbO}_{3}$ solid solution series (ASTM-34-1068; Labeau and Joubert, 1978, Table III).

TABle 5. X-ray diffraction patterns of loparite, 'irinite' and Th-rich loparite

\begin{tabular}{|c|c|c|c|c|c|c|c|c|c|c|}
\hline \multirow[b]{2}{*}{$h k l$} & \multicolumn{2}{|l|}{1} & \multicolumn{2}{|c|}{2} & \multicolumn{2}{|c|}{3} & \multicolumn{2}{|c|}{4} & \multicolumn{2}{|c|}{5} \\
\hline & $d$ & $I / I_{o}$ & $d$ & $I / I_{o}$ & $d$ & $I / I_{o}$ & $d$ & $I / I_{o}$ & $d$ & $I / I_{o}$ \\
\hline 100 & 3.870 & 2 & & & & & & & & \\
\hline 110 & 2.730 & 100 & 2.71 & 100 & 2.76 & 100 & 2.64 & 100 & 2.72 & 100 \\
\hline 111 & 2.225 & 50 & & & & & & & & \\
\hline 200 & 1.933 & 92 & 1.919 & 90 & 1.950 & 10 & 1.905 & 30 & 1.925 & 40 \\
\hline 211 & 1.578 & 95 & $\begin{array}{l}1.860 \\
1.569 \\
1.503\end{array}$ & $\begin{array}{l}20 \mathrm{~b} \\
80 \\
10\end{array}$ & 1.598 & 30 & 1.562 & 60 & 1.575 & 60 \\
\hline 220 & 1.367 & 70 & 1.360 & 40 & 1.383 & 20 & 1.355 & 30 & 1.368 & 30 \\
\hline 300 & 1.290 & 4 & & & & & & & & \\
\hline 310 & 1.225 & 25 & 1.216 & 30 & 1.233 & 15 & 1.214 & 20 & 1.222 & 20 \\
\hline 311 & 1.168 & 8 & 1.197 & 10 & & & & & & \\
\hline 222 & 1.117 & 13 & & & & & 1.111 & 5 & 1.118 & 5 \\
\hline 320 & 1.075 & 3 & & & & & & & & \\
\hline 321 & 1.035 & 38 & 1.028 & 60 & 1.042 & 20 & 1.029 & 10 & 1.034 & 10 \\
\hline 400 & 0.9680 & 5 & & & & & & & & \\
\hline 411 & & & & & & & 0.908 & 10 & 0.912 & 5 \\
\hline 420 & & & & & & & 0.864 & 10 & 0.865 & 5 \\
\hline 332 & & & & & & & 0.8245 & 5 & 0.8260 & 3 \\
\hline 422 & & & & & & & 0.7910 & 3 & & \\
\hline
\end{tabular}

1 synthetic $\mathrm{NaLaTi}_{2} \mathrm{O}_{6}: a=3.873 \AA$ (ASTM 39-65); 2 'irinite' (heated): $a=3.83 \AA$ (Borodin and Kazakova, 1954); 3 thorian loparite KHB-70, core (unheated): $a=3.902(2) \AA$; 4 thorian loparite KHB-70, core (heated): $a=3.841(1)$ $\AA$; 5 thorian loparite KHB-70, rim (heated): $a=3.867(2) \AA+3$ weak lines with $d=2.95 ; 1.795,1.535 \AA$ ( $3-5$ this work). $\mathrm{b}=$ broad line. 
The absence of superstructure reflections in the patterns of thorian loparite may result from its metamict state prior to heating, i.e. from failure to restore an initial apparently distorted structure of the mineral. Alternatively, stabilization of the cubic structure may result from the presence of minor cations in thorian loparite, e.g. Ca or Sr. This phenomenon refered to as stabilized polymorphism (Smirnova and Belov, 1969) is wellknown for $\mathrm{TiO}_{2}$ and $\mathrm{ZrO}_{2}$ polymorphs (Filatov and Frank-Kamenetskii, 1969; Grunin et al., 1983). To select between the two above alternatives, experimental studies of the solid solution series between loparite and Th-bearing end-members are being undertaken by us.

\section{Discussion}

At Khibina, Th-rich loparite occurs only in relation to the foyaite series (Borodin and Kazakova, 1954; Chakhmouradian and Mitchell, 1998; Kozyreva et al., 1991; Tikhonenkova et al., 1982). Zoned Th-rich loparite examined in this study crystallized at a late deuteric stage of the formation of foyaite pegmatites. At this stage, fluids enriched in $\mathrm{Ti}$ and incompatible elements $(\mathrm{Zr}, \mathrm{Nb}, \mathrm{Sr}, L R E E$, Th) gave rise to the assemblage of aegirine with loparite, eudialyte and Ti-silicates (astrophyllite, lorenzenite, lamprophyllite). In a similar paragenesis, loparite occurs in the foyaite pegmatites at Mt. Niorkpakhk (east of Mt. Eveslogchorr) and khibinite pegmatites at a number of localities in western Khibina (Chakhmouradian and Mitchell, 1998). In most of these occurrences, loparite is relatively Th-poor and compositionally evolves by enrichment in $\mathrm{Na}_{2} \mathrm{O}$ and $\mathrm{Nb}_{2} \mathrm{O}_{5}$ and depletion in $L R E E_{2} \mathrm{O}_{3}$ and $\mathrm{TiO}_{2}$ contents toward the rim. This trend coincides with the main magmatic trend of the compositional evolution of loparite in the nepheline-syenite complexes (Chakhmouradian and Mitchell, 1998; Mitchell and Chakhmouradian, 1996). The evolutionary trend from niobian loparite to thorian niobian loparite recognized in the present study has not been previously observed in alkaline rocks. Loparite from fenite-type rocks of the Paraná Basin carbonatite complexes has high $\mathrm{ThO}_{2}$ contents (up to 6.2 wt.\%), accompanied by enrichment in $\mathrm{Na}_{2} \mathrm{O}$ and $\mathrm{Nb}_{2} \mathrm{O}_{5}$ (lueshite), and depletion in $\mathrm{SrO}$ and $\mathrm{TiO}_{2}$ (tausonite) (Mitchell, 1996, Table 3.6). Th-enrichment (up to 4.9 wt. $\%$ $\mathrm{ThO}_{2}$ ) in the composition of perovskite from the carbonatite complexes of the Kola Peninsula is coupled with increasing $L R E E_{2} \mathrm{O}_{3}, \mathrm{Na}_{2} \mathrm{O}$ and $\mathrm{Nb}_{2} \mathrm{O}_{5}$, i.e. loparite and lueshite components (Chakhmouradian and Mitchell, 1997). In the Polino carbonatite, Th-bearing (1.5-1.7 wt.\% $\mathrm{ThO}_{2}$ ) perovskite has high $\mathrm{Fe}_{2} \mathrm{O}_{3}$ and $\mathrm{ZrO}_{2}$ contents (Lupini et al., 1992).

The limits of solubility between loparite $\left(\mathrm{NaLREETi}_{2} \mathrm{O}_{6}\right)$ and the thorium end-member compositions, $\mathrm{ThNb}_{4} \mathrm{O}_{12}, \mathrm{Na}_{2 / 3} \mathrm{Th}_{1 / 3} \mathrm{TiO}_{3}$ and $\mathrm{ThTi}_{2} \mathrm{O}_{6}$ are unknown. From structural data (Balić Žunić et al., 1984; Kovba and Trunov, 1963; Ruh and Wadsley, 1966; Zhu and Hor, 1995), it is expected that loparite forms a complete solid solution series with the former two compounds, and only a limited series with $\mathrm{ThTi}_{2} \mathrm{O}_{6}$. Experimental studies of the $\mathrm{NaLaTi}_{2} \mathrm{O}_{6}$ $-\mathrm{ThNb}_{4} \mathrm{O}_{12}, \quad \mathrm{NaLaTi}_{2} \mathrm{O}_{6}-\mathrm{Na}_{2} \mathrm{ThTi}_{3} \mathrm{O}_{9}$ and $\mathrm{NaLaTi}_{2} \mathrm{O}_{6}-\mathrm{ThTi}_{2} \mathrm{O}_{6}$ systems are being undertaken by the authors of this paper.

As evidenced by textural relationships and compositional data, the appearance of Na-poor Th-rich 'ceriobetafite' and belyankinite as mantles on thorian loparite was a result of metasomatic processes involving alkali-cation leaching and hydration. Note that the same processes brought about the replacement of nepheline and alkali feldspar present as relics in fibrous aegirine, by zeolites and eventually, by gibbsite. Metasomatites including albitites, albiteaegirine and albite-astrophyllite rocks are very common in the vicinity of pegmatite veins containing thorian loparite at Mt. Eveslogchorr. Hydrothermal solutions responsible for the metasomatic alteration most probably were derived from the phonolitic magma which produced the differentiated intrusion of nepheline syenites including foyaite and its precursor khibinite. An alternative source of such solutions could be a foidolite melt, as some authors suggest that the foidolites were emplaced later than the nepheline syenite intrusion (KostylevaLabuntsova et al., 1978a; Sniatkova et al., 1986).

\section{Conclusions}

In Na-LREE-Ti-dominant species of the perovskite group, $\mathrm{Th}^{4+}$ cations occupy large twelvecoordinated $A$ sites in the structure. The accommodation of Th into the structure is accompanied by appearance of vacancies at the $A$ sites at the expense of $\mathrm{Na}, L R E E$ and $\mathrm{Sr}$. Thorian loparite is essentially a member of the loparite $\left(\mathrm{NaLREETi}_{2} \mathrm{O}_{6}\right)$-lueshite $\left(\mathrm{NaNbO}_{3}\right)_{-}$ $\mathrm{ThTi}_{2} \mathrm{O}_{6}-\mathrm{ThNb}_{4} \mathrm{O}_{12}$ quaternary system with low 
or negligible contents of other end-member compositions. The mineral compositionally evolves from niobian loparite to niobian thorian and thorian niobian loparite. Metasomatic alteration of thorian loparite gave rise to 'ceriobetafite' and belyankinite with high $\mathrm{ThO}_{2}$ content. Thorian loparite is metamict or partly metamict and upon heating, regains a structure close to that of synthetic loparite $\mathrm{NaLaTi}_{2} \mathrm{O}_{6}$.

\section{Acknowledgements}

This work was supported by the Natural Sciences and Engineering Research Council of Canada and Lakehead University, Ontario (RHM, ARC). ARC also acknowledges support from St. Petersburg State University, Russia (grant Evolution of framework niobium-titanium oxides in carbonatite-bearing nepheline-syenite complexes). Alan MacKenzie and Keith Pringnitz are thanked for their assistance with the analytical work. Ann Hammond and Sam Spivak are thanked for thin section preparation and drafting services, respectively.

\section{References}

Balić Žunić, T., Šćavničar, S. and Grobenski, Z. (1984) The structure of thorium (IV) dititanium (IV) oxide, $\mathrm{ThTi}_{2} \mathrm{O}_{6}$ Croat. Chem. Acta, 57, 645-51.

Belous, A.G., Novitskaya, G.N., Gavrilova, L.G., Polyanetskaya, S.V. and Makarova, Z.Ya. (1985) Lanthanum titanate-zirconates with the perovskite structure. Sov. Prog. Chem., 51, 13-15.

Borodin, L.S. (1954) On accommodation of water in the crystal lattice of perovskite-group minerals. Doklady AN SSSR, 95, (in Russian), 873-5.

Borodin, L.S. and Kazakova M.E. (1954) Irinite - a new mineral from the perovskite group. Doklady AN SSSR, 97, (in Russian), 725-8.

Chakhmouradian, A.R. and Mitchell, R.H. (1997) Compositional variation of perovskite-group minerals from the carbonatite complexes of the Kola Alkaline Province,, Russia. Canad. Mineral., 35, $1293-310$.

Chakhmouradian, A.R. and Mitchell, R.H. (1998) Compositional variation of perovskite-group minerals from the Khibina alkaline complex, Kola Peninsula. Canad. Mineral., 36, (in press).

Filatov, S.K. and Frank-Kamenetskii, V.A. (1969) Structural characteristics of cubic $\mathrm{ZrO}_{2}$ stabilized by calcium. Sov. Phys. Cryst., 14, 414-5.

Galakhov, A.V. (1975) The petrology of the Khibina Alkaline Massif. Nauka Press, Leningrad, (in
Russian), 256 pp.

Gerasimovskii, V.I. and Kazakova, M.E. (1950) Belyankinite - a new mineral. Doklady AN SSSR, 71, (in Russian), 925-7.

Grunin, V.S., Razumenko, M.V., Patrina I.V., Filatov, S.K. and Alekseyeva, T.V. (1983) Mode of existence and abundance of $\mathrm{TiO}_{2}$-rutile, anatase and brookite. Doklady Earth Sci. Sect., 268, 149-50.

Haggerty, S.E. and Mariano, A.N. (1983) Strontianloparite and strontio-chevkinite: two new minerals in rheomorphic fenites from the Parana Basin carbonatites, South America. Contrib. Mineral. Petrol., 84, $365-81$.

Hogarth, D.D. (1961) A study of pyrochlore and betafite. Canad. Mineral., 6, 610-33.

Hogarth, D.D. (1989) Pyrochlore, apatite and amphibole: distinctive minerals in carbonatites. In: Carbonatites (K. Bell, ed), Unwyn Hyman, London, 105-48.

Kapustin, Yu.L. (1989) Rare earth-bearing pyrochlore from peralkaline pegmatites of the Khibina massif. New data on minerals (Trudy Mineral. Muz. AN SSSR), 36, (in Russian), 155-61.

Keller, C. (1965) Die Reaktion der Dioxide der Elemente Thorium bis Americium mit Niob- und Tantalpentoxid (The reaction of dioxides of the elements from thorium to americium with niobium and tantalum pentoxides). J. Inorg. Nucl. Chem., 27, $1233-46$.

Kogarko, L.N., Kononova, V.A., Orlova, M.P. and Woolley, A.R. (1995) Alkaline Rocks and Carbonatites of the World. Part 2: Former USSR. Chapman \& Hall, London, U.K., 226 pp.

Kostyleva-Labuntsova, E.E., Borutskii, B.E., Sokolova, M.N., Shliukova, Z.V., Dorfman, M.D., Dudkin, O.B., Kozyreva, L.V. and Ikorskii, S.V. (1978a) The Mineralogy of the Khibina Massif. Vol. 1. Nauka Press, Moscow, (in Russian), 228 p.

Kostyleva-Labuntsova, E.E., Borutskii, B.E., Sokolova, M.N., Shliukova, Z.V., Dorfman, M.D., Dudkin, O.B., Kozyreva, L.V. and Ikorskii, S.V. (1978b) The Mineralogy of the Khibina Massif. Vol. 2. Nauka Press, Moscow, (in Russian), $588 \mathrm{p}$.

Kovba, L.M. and Trunov, V.K. (1962) Double oxides containing tungsten, tantalum, or niobium. Doklady AN SSSR, 147, (in Russian), 622-4.

Kozyreva, L.V. (1990) Aegirine-feldspar veins in the north-eastern part of the Khibina massif. In: Alkaline Magmatism in the North-eastern Part of the Baltic Shield, Kola Sci. Centre Press, Apatity, (in Russian), $42-56$.

Kozyreva, L.V., Men'shikov, Yu.P. and Lednev, A.I. (1991) Loparite mineralization of the Khibina massif. In: New Data on the Rare-metal Mineralogy of the Kola Peninsula, Kola Sci. Centre Press, Apatity, (in Russian), 37-44. 
Krivokoneva, G.K. and Sidorenko, G.A. (1971) The essence of the metamict transformation in pyrochlores. Geochem. Int., 1971, 113-22.

Kukharenko, A.A. \& Bagdasarov. E.A. (1961) Perovskite from ultramafic-alkaline rocks of the Kola Peninsula. Trudy VSEGEI, 45, (in Russian), $37-66$.

Labeau, M. and Joubert, J.C. (1978) Etude cristallochimique des phases de type perovskite du systeme $\mathrm{Th}_{0.25} \mathrm{NbO}_{3}-\mathrm{NaNbO}_{3}$ (A crystal-chemical study of perovskite-type phases of the system $\mathrm{Th}_{\mathrm{O} .25} \mathrm{NbO}_{3}-\mathrm{NaNbO}_{3}$ ). J. Solid State Chem., 25, $347-53$.

Lupini, L., Williams, C.T. and Woolley, A.R. (1992) Zrrich garnet and $\mathrm{Zr}$ - and $\mathrm{Th}$-rich perovskite from the Polino carbonatite, Italy. Mineral. Mag., 56, 581-6.

Mitchell, R.H. (1996) Perovskites: a revised classification scheme for an important rare earth element host in alkaline rocks. In: Rare Earth Minerals: Chemistry, Origin and Ore Deposits (A.P. Jones, F. Wall and C.T. Williams, eds), Chapman \& Hall, London, $41-76$.

Mitchell, R.H. and Chakhmouradian, A.R. (1996) Compositional variation of loparite from the Lovozero alkaline complex, Russia. Canad. Mineral., 34, 977-90.

Mitchell, R.H. and Vladykin, N.V. (1993) Rare earth element-bearing tausonite and potassium barium titanates from the Little Murun potassic alkaline complex, Yakutia, Russia. Mineral. Mag., 57, $651-64$.

Mitchell, R.H., Chakhmouradian, A.R. and Yakovenchuk, V.N. (1996) "Nioboloparite": a reinvestigation and discreditation. Canad. Mineral., 34, $991-9$.

Náray-Szabó, I. (1947) The perovskite-structure family. Muegyet. Közlem., 1947, 30-41.

Nyquist, R.A. and Kagel, R.O. (1971) Infrared Spectra of Inorganic Compounds (3800-45 $\left.\mathrm{cm}^{-1}\right)$. Academic Press, New York, 495 pp.

Parker, R.L. and Sharp, W.N. (1970) Mafic-ultramafic igneous rocks and associated carbonatites of the Gem Park Complex, Custer and Fremont Counties, Colorado. US Geol. Surv. Prof. Paper, 649, 24 p.

Pilipenko, A.T., Shevchenko, L.L. and Patseliuk, V.A. (1971) Infrared spectra of some niobium minerals. Zh. Prikl. Spektr. (J. Appl. Spectr. ), 14, (in Russian), $638-43$.

Ruh, R. and Wadsley, A.D. (1966) The crystal structure of $\mathrm{ThTi}_{2} \mathrm{O}_{6}$ (brannerite). Acta Cryst., 21, 974-8.

Semenov, E.I. (1957) Oxides and hydroxides of titanium and niobium in the Lovozero alkaline massif. Trudy IMGRE, 1, (in Russian), 41-59. Abstracted in Amer. Mineral. (1958), 43, 1220-1.

Shannon, R.D. (1976) Revised effective ionic radii and systematic studies of interatomic distances in halides and chalcogenides. Acta Cryst., A32, 751-67.

Shilin, L.L., Burova, T.A. and Dmitrieva, M.T. (1966) Accessory pyrochlore in pegmatites of the Khibiny Tundra. In: Alkaline Rocks of the Kola Peninsula, Kola Sci. Centre Press, Apatity, (in Russian), 93-8.

Smirnova, N.L. and Belov, N.V. (1969) Isomorphism and related concepts in the light of crystal chemistry. Geokhim., 1969, (in Russian), 1291-301.

Smith, A.J. and Welch, A.J.E. (1960) Some mixed metal oxides of perovskite structure. Acta Cryst., 13, $653-6$.

Sniatkova, O.L., Proniagin, N.I., Markitakhina, T.M. and Efstaf'ev, A.S. (1986) New data on the structural position of urtite-ijolite-melteigites in nepheline syenites of the Khibina massif. In: Deposits of Non-metallic Mineral Resources in the Kola Peninsula, Kola Sci. Centre Press, Apatity, (in Russian), $11-17$.

Sych, A.M., Belokon', A.T., Dem'yanenko, V.P. and Eremenko, L.A. (1973) Vibration spectra of perovskite-structure rare-earth niobates. Ukrain. Phys. Zh. (Ukrain. J. Phys.), 18, (in Russian), $787-92$.

Tikhonenkova, R.P., Kazakova, M.E. and Kataeva Z.T. (1982) Chemistry of accessory loparite from alkaline rocks and its genetic significance. In: Accessory Minerals of Magmatic and Metamorphic Rocks, Nauka Press, Moscow, (in Russian), 150-61.

Trunov, V.K. and Kovba L.M. (1963) X-ray analysis of thorium tungstate and molybdenate. Vest. Mosk. Univ., Ser. II Khim., 18, (in Russian), 60-3.

Vidyasagar, K. and Gopalakrishnan, J. (1982) New vanadium oxides with perovskite type structure: $\mathrm{AThV}_{2} \mathrm{O}_{6}(\mathrm{~A}=\mathrm{Ca}, \mathrm{Sr})$. Indian J. Chem., 21A, 716-7.

Vlasov, K.A., Kuz'menko, M.Z. and Es'kova, E.M. (1966) The Lovozero Alkaline Massif. Oliver \& Boyd Ltd., Edinburgh, U.K., 627 pp.

Voloshin, A.V., Pakhomovskii, Ya.A., Pushcharovskii, D.Yu., Nadezhina, T.N., Bakhchisaraitsev, A.Yu. and Kobiashev, Yu.S. (1989) Strontian pyrochlore: Composition and structure. New data on minerals (Trudy Mineral. Muz. AN SSSR), 36, (in Russian), $12-24$.

Zak, S.I., Kamenev, E.A., Minakov, F.V., Armand, A.L., Mikheichev, A.S. and Petersil'e, I.A. (1972) The Khibina Alkaline Massif. Nedra Press, Leningrad, (in Russian), 175 pp.

Zhu, W.J. and Hor, H.P. (1995) A new titanium perovskite oxide, $\mathrm{Na}_{2 / 3} \mathrm{Th}_{1 / 3} \mathrm{TiO}_{3}$. J. Solid State Chem., 120, 208-9.

[Manuscript received 6 May 1997:

revised 9 September 1997] 